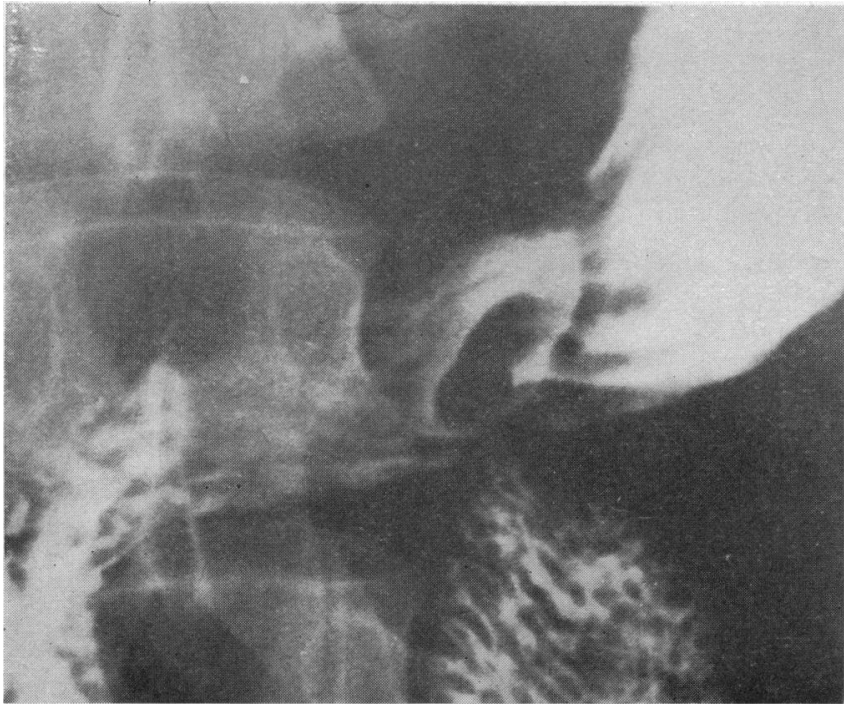

Fig. 1.-Case 1. Gastro-duodenal mucosal prolapse.

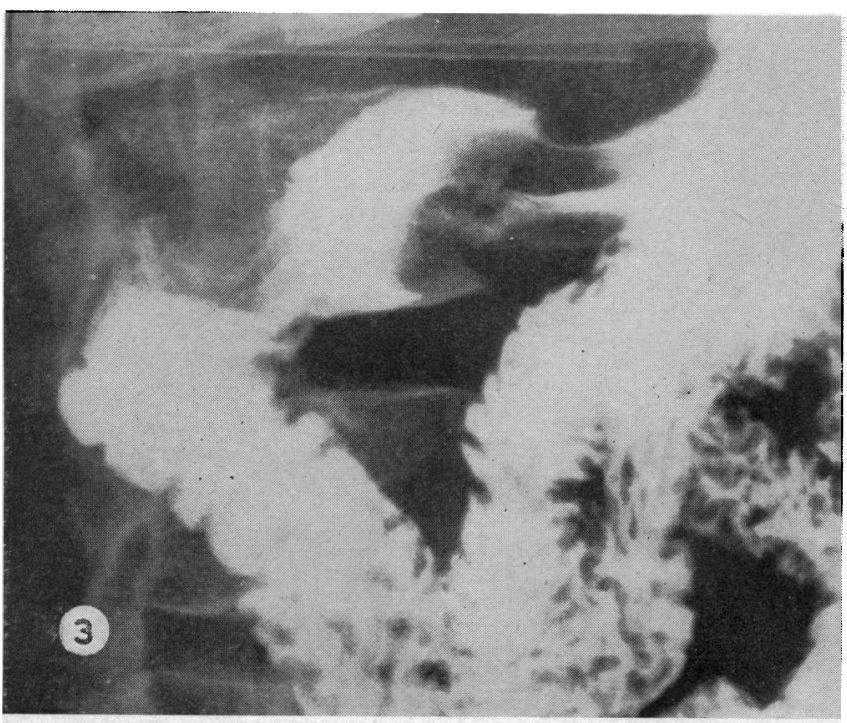

Fig. 3.-Case 3. Gastro-duodenal mucosal prolapse.

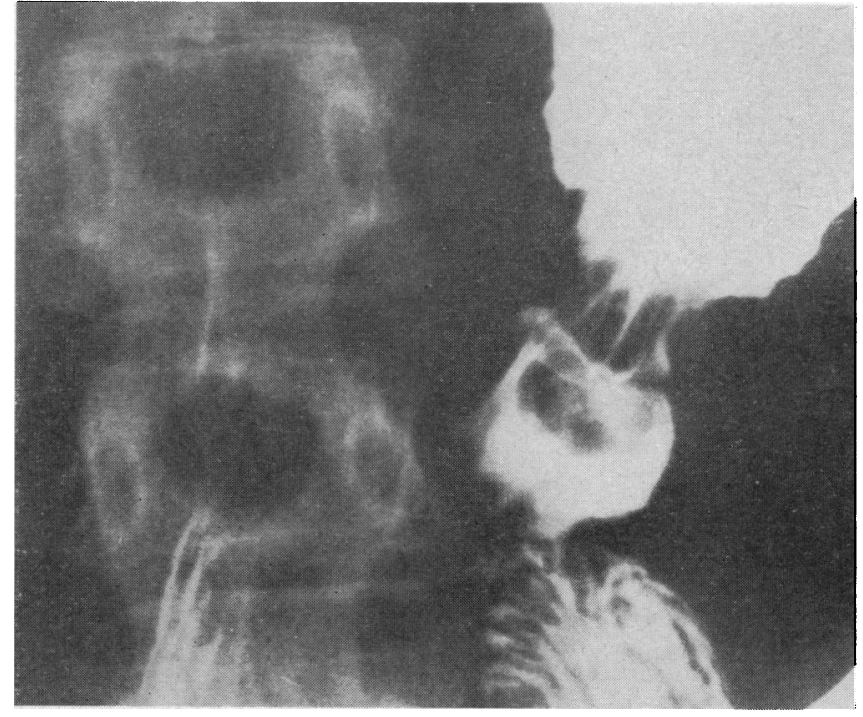

FIG. 2.-Case 2. Gastro-duodenal mucosal prolapse.

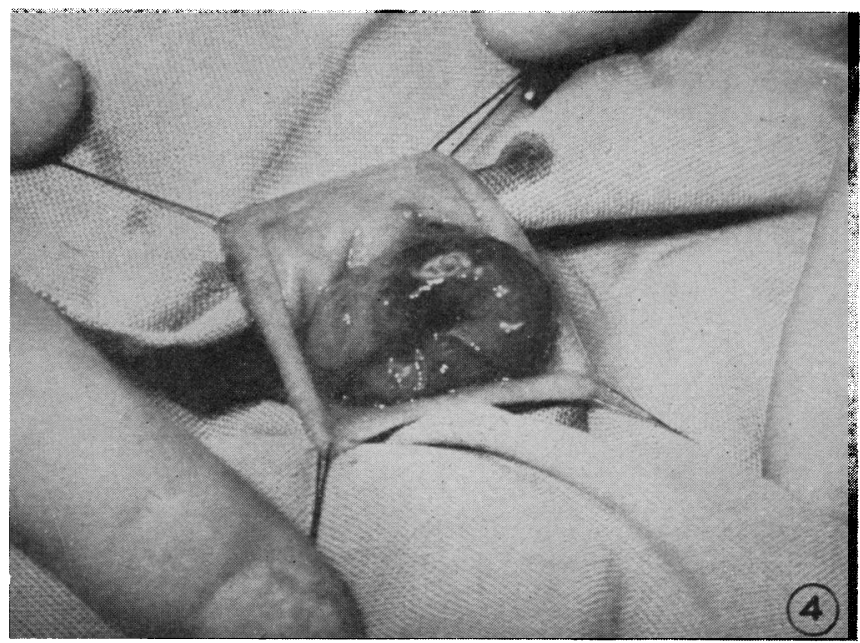

Fig. 4.-Case 3. Appearance of mucosal prolapse at operation viewed from the duodenal aspect.

Fig. 1.-Case 1. Pseudo-fractures in right fourth and fifth ribs and left scapula.

D. J. C. FELTON AND W. D. STONE : OSTEOMALACIA IN ASIAN IMMIGRANTS DURING PREGNANCY

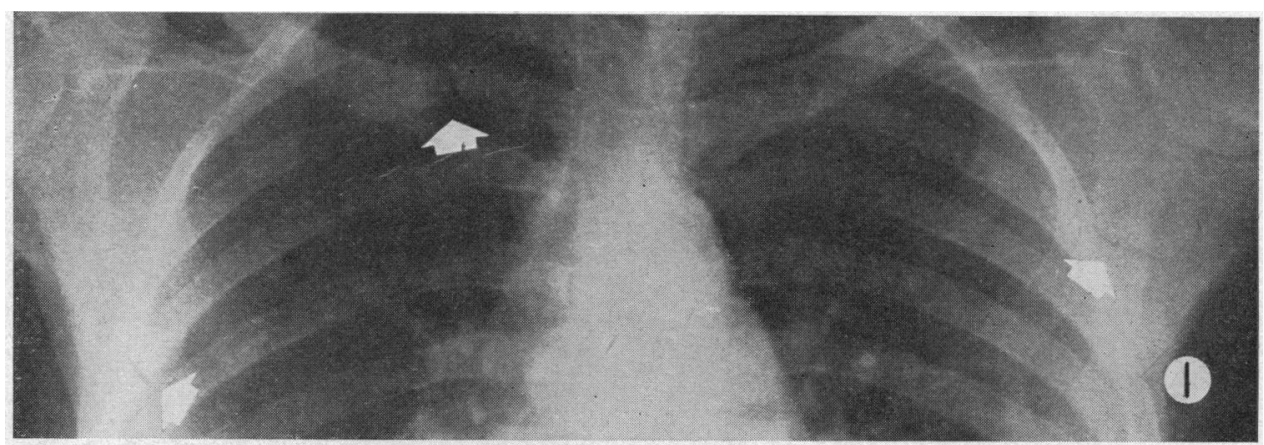

Fig. 2.-Case 3. Pseudo-fractures of both eleventh ribs. 
Drachman, D. A., and Adams, R. D. (1962). Arch. Neurol. (Chic.), 7,

Haymaker, W. (1949). 7. Neuropalh. exp. Neurol., 8, 132.

Jellinger, K., Poetsch, F., and Seitelberger, F. (1964). Acta neuropath. (Berl.), 3, 278.

Leider, W., Magoffin, R. L., Lennette, E. H., and Leonards, L. N. R. (1965). New Engl. ‡. Med., 273, 341.
MacCallum, F. O., Potter, J. M., and Edwards, D. H. (1964). Lancet, 2, 332 .

Pierce, N. F. Portnoy, B., Leeds, N. E., Morrison, R. L., and Wehrle, P. F. (1964). Neurol. (Minneap.), 14, 708.

Ross, C. A. C., and Sharpe, J. H. S. (1965). Lancet, 2, 708.

Smith, M. G., Lennette, E. H., and Reames, H. R. (1941). Amer. F. Path., 17. 55.

\title{
Osteomalacia in Asian Immigrants During Pregnancy
}

\author{
D. J. C. FELTON,* M.B., M.R.c.o.g.; W. D. STONE, † B.M., M.R.C.P.
}

[With Special Plate]

Brit. med. F., 1966, 1, 1521-1522

Rickets and mild osteomalacia have been found in a number of Asian immigrants to the United Kingdom (Dunnigan et al., 1962). Pregnancy can precipitate florid osteomalacia in this group, but in women who speak little English it is not easy to distinguish significant symptoms from the muscular pains common in pregnancy.

\section{Case 1}

A Punjabi para-4 aged 29, resident in Birmingham for four years, complained of severe headache and limb pains during her fourth pregnancy in 1963. In January 1964 when 10 weeks pregnant she was admitted to hospital with vomiting and generalized aches and pains. A urinary infection was treated. When 18 weeks pregnant she complained of severe pains in the back, pelvis, and thighs, made worse by sitting or bending. Six weeks later difficulty in walking and muscular weakness were also present ; rest in hospital produced only slight improvement. When 35 weeks pregnant she was admitted because "she walks with great difficulty, almost in agony." Bony tenderness was widespread and the diagnosis of osteomalacia was suggested. Pseudo-fractures were seen in the right fourth and fifth ribs and in the left scapula (Special Plate, Fig. 1). The iliac crest was so soft that it was easily cut with a scalpel, but preparation of the biopsy was unsatisfactory. Treatment with calcium and vitamin $\mathrm{D}$ resulted in slow but steady improvement, and she was discharged free of pain two weeks after a normal labour and delivery of a healthy child weighing $7 \mathrm{lb} .11 \mathrm{oz}$. $(3,490 \mathrm{~g}$.). There was still some muscular weakness, but six weeks later she was walking normally. Four months later an $x$-ray examination showed that the fractures had healed.

\section{Case 2}

A Punjabi para-5 aged 37 had been in Birmingham for six years, and her last three pregnancies had been in this country. She was first seen in the antenatal clinic when 34 weeks pregnant. She had difficulty in walking, and had a waddling gait. She complained of pain in the back and pelvis and was tender over the lumbar spine. An $x$-ray film of the pelvis showed generalized demineralization. A diagnosis of osteomalacia was made and treatment begun with calcium and vitamin D. She was discharged after five weeks' treatment, free of pain and walking normally, 10 days after a normal labour and delivery of a healthy child weighing $6 \mathrm{lb} .7 \mathrm{oz}$. $(2,920 \mathrm{~g}$.) .

* Senior Registrar in Obstetrics, Dudley Road Hospital, Birmingham. Present appointment: Senior Registrar, United Birmingham Hospitals.

† Senior Registrar in Medicine, Dudley Road, Hospital, Birmingham.

\section{Case 3}

A Punjabi primigravida aged 21 had been in the United Kingdom for 10 months. When 35 weeks pregnant she was admitted as an emergency with pain in the back. There was pain and tenderness in both renal angles, but the diagnosis of pyelonephritis was rejected after two negative cultures of the urine. An $x$-ray film (Special Plate, Fig. 2) showed pseudo-fractures of both 11 th ribs, and it was realized that tenderness was localized to these points. There was no history of trauma and she had no cough. After one week's treatment with calcium and vitamin $\mathbf{D}$ pain was much improved. A bone biopsy two weeks later showed borderline osteomalacia. Labour and delivery were normal.

\section{Investigations}

For all three cases, levels of serum calcium, phosphate, and alkaline phosphatase, and the urinary calcium output, are shown in the Table. All patients had normal plasma proteins, blood urea, serum electrolytes, and stool-fat excretion. They were only mildly anaemic. Cases 2 and 3 showed a slight respiratory alkalosis, ascribed to hyperventilation in these anxious women. None had glycosuria, but Case 3 showed a mild generalized amino-aciduria, presumably secondary to the nutritional deficiencies (Harrison and Harrison, 1957).

\section{Discussion}

Rickets and osteomalacia are common in Northern India and Pakistan (Wilson, 1931 ; Taylor and Marshall Day, 1940), the main cause being widespread dietary deficiencies of vitamin D

\begin{tabular}{|c|c|c|c|c|c|c|c|c|}
\hline \multirow[b]{2}{*}{$\begin{array}{l}\text { Case } \\
\text { No. }\end{array}$} & \multicolumn{4}{|c|}{ Before Treatment } & \multicolumn{4}{|c|}{ After 4-5 Weeks' Treatment } \\
\hline & $\begin{array}{c}\text { Serum } \\
\text { Calcium } \\
\text { (mg./ } \\
100 \mathrm{ml} .)\end{array}$ & $\begin{array}{c}\text { Serum } \\
\text { Phos- } \\
\text { phate } \\
\text { (mg./ } \\
100 \mathrm{ml} .)\end{array}$ & $\begin{array}{c}\text { Serum } \\
\text { Alkaline } \\
\text { Phos- } \\
\text { phatase } \\
\text { (K-A. } \\
\text { Units) }\end{array}$ & $\begin{array}{l}\text { Urinary } \\
\text { Calcium } \\
\text { (mg./ } \\
24 \text { hr.) }\end{array}$ & $\begin{array}{l}\text { Serum } \\
\text { Calcium }\end{array}$ & $\begin{array}{l}\text { Serum } \\
\text { Phos- } \\
\text { phate }\end{array}$ & $\begin{array}{l}\text { Serum } \\
\text { Alkaline } \\
\text { Phos- } \\
\text { phatase }\end{array}$ & $\begin{array}{l}\text { Urinary } \\
\text { Calcium }\end{array}$ \\
\hline $\begin{array}{l}1 \\
2 \\
3\end{array}$ & $\begin{array}{l}8 \cdot 7 \\
8 \cdot 1 \\
9 \cdot 1\end{array}$ & $\begin{array}{l}2.0 \\
3.3 \\
2.5\end{array}$ & $\begin{array}{c}171 \\
56 \\
24 \cdot 5\end{array}$ & $\begin{array}{l}77 \\
53 \\
77\end{array}$ & $\begin{array}{r}10 \cdot 1 \\
9 \cdot 6 \\
9 \cdot 4\end{array}$ & $\begin{array}{l}2 \cdot 7 \\
3 \cdot 7 \\
4.9\end{array}$ & $\begin{array}{l}30 \\
14 \cdot 7 \\
14 \cdot 7\end{array}$ & $\begin{array}{l}40 \\
69 \\
79\end{array}$ \\
\hline
\end{tabular}

Normal ranges: serum calcium, 9.3-10.4 mg./100 ml.; serum phosphate, 2.8$5.0 \mathrm{mg} . / 100 \mathrm{ml}$.; serum alkaline phosphatase, $4 \cdot 5-16 \mathrm{~K}-\mathrm{A}$. units; urinary calcium, 
and calcium. In women frequent pregnancies and prolonged breast-feeding accentuate these deficiencies. Lack of sunlight is another important factor; in the Punjab, Moslem women may live in purdah, while Hindus also receive inadequate exposure through living in overcrowded, sunless houses.

In the United Kingdom rickets and osteomalacia are now usually secondary to steatorrhoea or to renal tubular abnormalities, though osteomalacia has been described in food-faddists (Dent, 1957) and in elderly people living on inadequate diets (Gough et al., 1964). A survey of Pakistanis in Glasgow, however (Dunnigan et al., 1962), revealed biochemical osteomalacia in several adults, both men and women, though none had clinical or radiological evidence of the disease. Their diets contained adequate calories and protein, but there was a lack of foods containing calcium and vitamin D. Dunnigan and Smith (1965) felt that pigmentation and lack of sunlight were also important in producing late rickets in this community. Our patients did have small intakes of calcium and vitamin $\mathrm{D}$, and had presumably arrived in this country with depleted reserves, though their physique was excellent. Their adherence to traditional dress further reduces their exposure to sunlight, and was probably an important aetiological factor. We excluded intestinal and renal disease.

In two patients the diagnosis was made on clinical grounds. They complained of severe pain in the back, pelvis, and legs, the bones were tender, and movements of the hips and shoulders painful. There was marked muscle weakness and fatigue. The women could not sit up for more than a few minutes unsupported and had difficulty getting in and out of bed. Their broad-based, waddling gait was characteristic and was a gross exaggeration of that normally seen in pregnancy. In the third patient the pain was localized to the sites of rib fractures, and generalized symptoms were absent. In two patients the disease had a relatively acute onset in late pregnancy, while in the other (Case 1) it had clearly been present in the previous pregnancy in a less severe form. Her symptoms had improved after delivery only to suffer an acute exacerbation early in the next pregnancy.

$X$-ray examination in one patient showed pseudo-fractures, which are diagnostic of osteomalacia (Albright et al., 1946), and in two there was generalized demineralization. In the third patient the discovery of fractures on $x$-ray examination was the main diagnostic clue in the absence of the more generalized symptoms displayed by the other women. Biochemical tests were typical and grossly abnormal in two patients, but only mildly so in the third. In the latter case the serum alkaline phosphatase was not above the normal for this stage of pregnancy (Curzen and Morris, 1965).

It is easy to disregard complaints of generalized pain in women with little command of English. This is particularly so in pregnancy, when the relaxation of pelvic ligaments results in altered posture and muscular strain. This was the reason for the delay in diagnosis in the first patient, whereas, in the second, awareness of the condition allowed a confident clinical diagnosis on her first visit to the antenatal clinic.

As extensive radiological investigations are undesirable in pregnancy, it is fortunate that simple biochemical tests can often confirm a clinical suspicion. Treatment with vitamin $\mathrm{D}$ (3,000-6,000 I.U. daily) and calcium results in rapid clinical response, and pain soon disappears. Other causes of osteomalacia must be excluded in Asians as well as in Europeans, particularly if there is a slow response to treatment.

\section{Summary}

Osteomalacia of dietary origin was diagnosed in three pregnant women, members of the Asian community in Birmingham. It is important to exclude this disease in immigrants who complain of skeletal pains, particularly during pregnancy.

AdDENDUM.-During the last six months three similar cases have been seen in the obstetric department of this hospital.

We wish to thank Miss A. Reynolds and Mr. G. Mitchell for allowing us to publish details of patients under their care, Mr. W. B. Yeoman for the biochemical data and advice, and Dr. A. W. Robinson for reviewing the $x$-ray films. Dr. H. Thompson kindly reported on the bone biopsy.

\section{REFERENCES}

Albright, F., Burnett, C. H., Parson, W., Reifenstein, E. C., and Roos, A. (1946). Medicine (Baltimore), 25, 399.

Curzen, P., and Morris, I. (1965). f. Obstet. Gynaec. Brit. Cwlth, 72, 397.

Dent, C. E. (1957). Proc. roy. Soc. Med., 50, 377

Dunnigan, M. G., Paton, J. P. J., Haase, S., McNicol, G. W., Gardner, M. D., and Smith, C. M. (1962). Scot. med. F., 7, 159. - and Smith, C. M. (1965). Ibid., 10, 1.

Gough, K. R., Lloyd, O. C., and Wills, M. R. (1964). Lancet, 2, 1261. Harrison, H. E., and Harrison, H. C. (1957). F. Amer. med. Ass., 164, 1571 .

Taylor, G. F., and Day, C. D. M. (1940). Brit. med. F., 2, 221.

Taylor, G. F., and Day, C. D. M.

\section{Medical Memoranda}

\section{Quinidine-induced Paroxysmal Ventricular Fibrillation Treated with Propranolol}

Brit. med. F., 1966, 1, 1522-1523

Ventricular fibrillation is known as an occasional dangerous complication of quinidine therapy, and is the most likely cause of sudden death during attempts to convert atrial fibrillation to sinus rhythm with this drug (Thomson, 1956 ; Selzer and Wray, 1964).

This paper describes the apparently specific action of the beta-adrenergic-blocking drug propranolol (Inderal) in treating such a dysrhythmia following a course of quinidine.

\section{CASE RÉPORT}

A 37-year-old woman with mild asymptomatic mitral stenosis developed atrial fibrillation and cardiac failure following a pulmonary embolus after her sixth pregnancy. When her condition had been controlled with digoxin, diuretics, and anticoagulants, it was decided to attempt conversion of her arrhythmia to sinus rhythm with quinidine. At this time she was taking digoxin $0.25 \mathrm{mg}$. daily.

After a test dose of $0.3 \mathrm{~g}$. quinidine on the previous day she was given $0.3 \mathrm{~g}$. every two hours for seven doses. Clinical observation and repeated electrocardiograms (E.C.G.) afforded no evidence of toxicity, and the last dose of quinidine was given at 6 p.m.

At 1 a.m. the same night the patient had a brief syncopal attack from which she recovered spontaneously. At 8 a.m. she had a further syncopal attack, and an E.C.G. taken shortly afterwards showed a bigeminal rhythm in which the multiform ventricular ectopic beats had a constent coupling time. Multiple syncopal

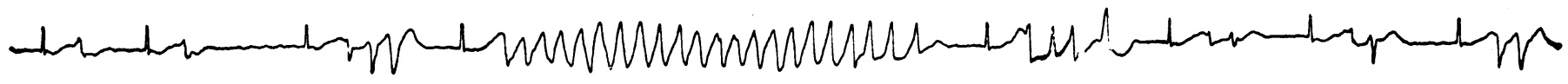

FIG. 1.-Electrocardiogram taken during syncopal attack. 